\author{
Jurnal Ekonomi Modernisasi \\ http://ejournal.unikama.ac.id/index.php/JEKO \\ JEM 13 (2) 2017, 78-93
}

\title{
Model Pengembangan Sistem Informasi Akuntansi Taman Pendidikan Alquran
}

\author{
Devia Nurbatin \\ Sekolah Tinggi Ilmu Ekonomi Indocakti
}

\begin{abstract}
The purpose of this research to generate models of Accounting System in the form of Standard Operating Procedures (SOP) for guidance on the accuracy of management information for the management TPQ Al-Hidayah Dau Malang. The research phase starting from problem identification, data collection, preparation of the product, product testing (validation expert) and penyepurnaan final product. Data collection techniques that focus group discussions, observation, interview and questionnaire (questionnaire). Questionnaire as an expert validation instrument consists of four aspects, namely ratings aspects of usability, simplicity, completeness and legibility. The technique used to analyze data on the validation of scoring is to use the average value of the test. The study produced a quality system in the form of 10 SOP Flow Information Financial Recording and 8 SOP Flow of Information Management and Financial Control that shows the application of SOP has to be implemented and the feasibility of value according to user needs.
\end{abstract}

Keywords: Information Accounting Systems; Standard Operating Procedure; TPQ

Abstrak

Tujuan penelitian ini adalah untuk menghasilkan model sistem akuntansi dalam bentuk Standard Operating Procedures (SOP) sebagai panduan keakuratan Informasi pengelolaan Manajemen untuk TPQ Al-Hidayah DAU Malang. Tahap penelitian dimulai dari identifikasi masalah, pengumpulan data, penyusunan produk, uji produk (validasi ahli) dan penyempurnaan produk akhir. Tehnik pengumpulan data yaitu Focus Group Discussion, Observasi, Wawancara dan kuisioner. Angket sebagai instrumen validasi ahli terdiri dari 4 aspek penilaian yaitu aspek kegunaan, kemudahan, kelengkapan dan keterbacaan. Teknik yang digunakan untuk menganalisis data hasil skoring validasi adalah dengan menggunakan nilai uji rata-rata. Penelitian ini menghasilkan sistem mutu dalam bentuk 10 SOP Alur Informasi Pencatatan Keuangan dan 8 SOP Alur Informasi Pengelolaan dan Pengendalian Keuangan yang menunjukkan penerapan SOP memiliki kelayakan nilai untuk diimplementasikan dan sesuai dengan kebutuhan pengguna.

Kata kunci: Sistem Informasi Akuntansi; Standar Operasional Prosedur; TPQ

\begin{tabular}{ll}
\hline Permalink/DOI & $:$ http://dx.doi.org/10.21067/jem.v13i2.1773 \\
Cara mengutip & $: \begin{array}{l}\text { Nurbatin, D. (2017). Model Pengembangan Sistem Informasi Akuntansi Taman } \\
\text { Pendidikan Alquran. Jurnal Ekonomi Modernisasi, 13(2), 78-93. doi:http:// } \\
\end{array} \quad \begin{array}{l}\text { dx.doi.org/10.21067/jem.v13i2.1773 } \\
\text { Sejarah Artikel }\end{array} \quad$ Artikel diterima $:$ Mei 2016; direvisi Juni 2017; diterima Juli 2017
\end{tabular}

Alamat korespondensi :

Sekolah Tinggi Ilmu Ekonomi Indocakti

ISSN 0216-373X (cetak)

Jl. Besar Ijen No. 90-92, Malang Indonesia

ISSN 2502-4578 (online)

E-mail: devia.nurbatin@gmail.com 


\section{Pendahuluan}

Upaya meningkatkan kualitas dari sistem mutu pendidikan agama dan kelola usaha pendidikan non-formal berbasis agama Islam dilingkungan tempat tinggal, serta merespon kebutuhan masyarakat sekitar terhadap pendidikan Alquran bagi anak usia dini sebagai pendidikan dasar mereka maka dibentuk dan dikembangkan Taman Pendidikan Alquran (TPQ). TPQ merupakan lembaga pendidikan non formal yang didirikan sebagai respon terhadap kebijakan pemerintah tentang pembinaan dan peningkatan mutu madrasah di Indonesia.

Permasalahan umum yang dihadapi oleh manajemen TPQ adalah pengelolaan keuangan. Pelaporan dan pengelolaan keuangan di lembaga berkaitan dengan penghimpunan, pengelolaan, pelaporan, pencatatan dan pelaporan keuangan dalam rangka pengawasan, pengendalian serta pemeriksaan untuk mencapai efisiensi dan efektifitas. Hal penting karena faktor akuntabilitas dan transparansi setiap penggunaan keuangan yang bersumber dari pemerintah, masyarakat dan lainnya. Oleh karena itu, perlu mekanisme sistem alur pencatatan transaksi dana masuk dan keluar agar dapat disusun laporan keuangan yang akuntabel.

Selama ini pengelolaan TPQ masih bersifat kekeluargaan, karena belum ada informasi yang dapat digunakan untuk pengambilan keputusan yang memungkinkan penilaian kinerja untuk dijadikan standar bagi pengelolaan TPQ lain. Informasi yang dihasilkan sistem akuntansi seperti alur pencatatan dan pengelolaan keuangan, jumlah siswa, perkembangan kemampuan siswa, informasi nilai asset masih bersifat parsial dan belum akurat. Laporan keu- angan memungkinkan pemilik memperoleh informasi yang tersusun secara sistematis, sehingga pemilik dapat mengetahui keseimbangan hak dan kewajiban yang dimiliki. Hal ini dapat berpengaruh positif terhadap keputusan yang diambil oleh pemilik untuk pengembangan organisasi karena pengambilan keputusan berdasarkan kondisi keuangan yang konkret dan dilaporkan secara lengkap dan bukan hanya didasarkan pada asumsi saja.

Alur pencatatan dan pengelolaan keuangan yang belum berdasarkan sistem informasi akuntansi hanya disusun kas keluar dan kas masuk secara manual dan tidak didukung bukti transaksi, sehingga aspek pengendalian manajemen sebagai perencanaan dan pengelolaan TPQ dinilai belum akurat sesuai standar mutu pengelolaan manajemen. Untuk itu, perlu dirancang suatu sistem informasi akuntansi berbasis sistem mutu yang mampu memberikan secara akurat, cepat dan tepat bagi pihak manajemen sebagai informasi untuk pengambilan keputusan khususnya terkait informasi alur pencatatan dan pengelolaan keuangan serta tentang proses pelaksanaan belajar mengajar pada TPQ.

Penelitian terkait perancangan dan implementasi sistem informasi akuntansi di TPQ telah dilakukan Gantino (2014) di Taman Pendidikan A-Qur'an di Kecamatan Pulogadung Jakarta Timur. Temuan penelitian menegaskan bahwa pengelolaan manajemen TPQ harus didukung teknologi informasi agar informasi yang dihasilkan terkait keuangan dan administrasi akademik lebih akurat dan cepat diakses. Adapun penelitian yang dilakukan Santoso dan Nurwati (2016) menitikberatkan pada upaya mempermudah mengorganisir data, 


\section{Devia Nurbatin / Model Pengembangan Sistem Informasi Akuntansi....}

menampung data dan menyediakan setiap saat informasi yang diperlukan bagi manajemen untuk mengambil keputusan di TPQ SAQUBI terutama ketika pendaftaran siswa baru agar lebih tertib adminstrasi dan disiplin dalam menyimpan data, sehingga sistem informasi yang dibangun dapat mempermudah kegiatan operasional organisasi dan kemudahan untuk mengetahui kondisi siswa pada TPQ SAQUBI Pondok Aren melalui laporan administrasi pendaftaran.

Hal ini juga diungkapkan pada penelitian Susanto (2016) yang menyatakan "all organizations need information as a basis for decision making. Information has become a major resource for most organizations, both for profit and non porfit organization. In recent years, accounting information systems (AIS) has become a system that is very important in an organization because it generates important information for organization". Oleh karena itu diperlukan pengendalian internal untuk meminimalkan kecurangan penggunaan sistem informasi dalam menghasilkan informasi akuntansi yang berkualitas dan transaparansi. Berdasarkan hal tersebut pula konsisten dengan penelitian Kalu (2011) yang menyatakan sistem informasi akuntansi sangat tergantung pada penggunaan dan pengelolaan data dalam menyusun standar manajemen mutu dan kualitas data dalam sistem informasi akuntansi.

Perbedaan penelitian ini dengan penelitian sebelumnya adalah pengembangan sistem akuntansi berbasis sistem mutu melalui rancangan sistem informasi akuntansi berbentuk Standar Operasional Prosedur (SOP) akuntansi dan pengelolaan keuangan agar pengelolaan, pengawasan, pengendalian terhadap fungsi-fungsi manajemen di TPQ dapat efektif dan efisien dan mempunyai standar mutu pendidikan nonformal. Penelitian yang dilakukan oleh Gantino (2014); Santoso dan Nurwati (2016); Susanto (2016) dan Chibueze (2011) berorientasi pada perancangan sistem informasi teknologi sebagai pendukung kelola manajemen yang tertata rapi namun manual, serta Susanto (2016) dan Chibueze (2011) mengarah pada meningkatkan sistem manajemen mutu untuk menghasilkan informasi akuntansi dan pengendalian internal pada objek penelitian organisasi formal yang besar. Adapun pada penelitian ini dilakukan pada organisasi pendidikan yang non formal.

Penelitian ini dilakukan di TPQ Al Hidayah yang berlokasi di Kecamatan Dau Kabupaten Malang. Sesuai dengan studi pendahuluan yang dilakukan dapat dijelaskan bahwa saat ini terdapat masalah yaitu yaitu alur pencatatan dan penyusunan buku besar hingga menjadi laporan keuangan terkait informasi dana kas masuk misalnya jumlah sumber dana donatur ke TPQ atau pembayaran SPP siswa-siswi dan dana kas keluar misalnya pengadaan media pembelajaran, buku penunjang siswa, pelatihan gutu TPQ dan pembiayaan acara pawai pondok Ramadhan sehingga informasi terkait hal tersebut tidak akurat. Oleh karena itu, perlu dirancang sistem informasi akuntansi berbentuk standar operasional prosedur.

Tujuan penelitian ini adalah untuk mengembangkan dan menerapkan model penelitian sistem mutu akuntansi pada pengelolaan manajemen Taman Pendidikan Al-Quran Dau Malang. Hal itu dilakukan dengan menyusun sistem mutu da- 
lam bentuk Standard Operational Prosedur (SOP) Alur Informasi Pencatatan Keuangan dan SOP Alur Informasi Pengelolaan Keuangan. SOP ini sebagai landasan dalam menjalankan pelaksanaan manajemen TPQ Al-Hidayah Dau Malang yang berbasis pendidikan non-formal serta memiliki substansi dasar penelitian bidang Akuntansi dan Manajemen Keuangan. Nurbatin (2016) menyatakan bahwa organisasi bisnis biasanya terbentuk ke dalam suatu struktur formal yang terdiri dari berbagai prosedur, proses dan aturan yang rasional (termasuk sistem pengelolaan keuangan formal dan non-formal). Fitur tersebut juga mencakup otorisasi dan prosedur pengambilan keputusan yang jelas, kebijakan personil, teknik pengukuran, pengawasan dan pengendalian kinerja organisasi, pernyataan misi dan sasaran organisasi, penggunaan dokumen tertulis untuk mencatat aktivitas organisasi. Sedangkan menurut Setiawati (2015) SOP merupakan bentuk baku proses kerja yang digunakan sebagai panduan dalam bekerja.

Spesifikasi produk hasil penelitian ini adalah sistem mutu yang akan dijadikan standar prosedur baku dan tertulis yang dapat digunakan sebagai panduan keakuratan informasi pengelolaan manajemen untuk TPQ Al-Hidayah Dau Malang.

\section{Tinjauan Pustaka}

\section{Standar Oprasional Prosedur berbasis Sistem Mutu}

Sistem secara umum merupakan sekelompok unsur yang erat hubungannya satu dengan yang lain yang berfungsi bersama-sama untuk mencapai tujuan tertentu. Karakteristik sistem yaitu sebagai komponen sistem (components), sebagai batasan sistem (boundary), sebagai lingkungan luar sistem (environment), sebagai penghubung sistem (interface) yang menghubungkan sistem dengan subsistem lain, sebagai masukan sistem (input), sebagai keluaran (output), sebagai pengolahan sistem (proces) dan sebagai sasaran sistem (objective) (Mulyadi, 2016:12). Sistem merupakan kegiatan yang memproses input sehingga menjadi output. Input memiliki peran penting karena memudahkan dalam pemrosesan data. Metode pemrosesan yang efektif dan efisien akan menghasilkan output yang sesuai dengan yang diinginkan.

Sistem mutu menurut Atmoko (2010) merupakan bagian dari instrumen pengelolaan bisnis manajemen yang merupakan standar operasional prosedur berlandaskan sistem manajemen kualitas (Quality Management System). Adapun manajemen kualitas adalah sekumpulan prosedur yang terdokumentasi dan praktek -praktek standar untuk manajemen sistem yang bertujuan menjamin kesesuaian dari suatu proses dan produk (barang atau jasa) terhadap kebutuhan atau persyaratan tertentu. Sistem manajemen kualitas berfokus pada konsistensi dari proses kerja. Standar Oprational Prosedur adalah suatu perangkat lunak pengatur yang mengatur tahapan suatu proses kerja atau prosedur kerja. Menurut Prasanna (2013) SOP adalah " A routine or repetitiveactivity is documented to form a set of writteninstructions, such manual which provides individuals or the employees to perform the job properly which facilitates integrity and quality in the end product 


\section{Devia Nurbatin / Model Pengembangan Sistem Informasi Akuntansi....}

or service". Berdasarkan hal tersebut, SOP merupakan representatif manual dari aktivitas rutin yang ditulis dalam dokumen sebagai instruksi kerja bagi setiap karyawan untuk prosedur kerja sebagai upaya meningkatkan integritas kerja agar menghasilkan ouput layanan berkualitas. Sedangkan menurut Nurbatin (2016) SOP adalah prosedur kerja bersifat tetap, rutin, dan tidak berubah-ubah dan prosedur kerja tersebut dibakukan menjadi dokumen tertulis. Tujuan dibuatnya SOP antara lain adalah supaya karyawan selalu bisa menjaga konsistemsi dalam melaksanakan pekerjaan sehari-hari. Adanya SOP, karyawan akan tahu dengan jelas peran dan tanggung jawab sehingga mempermudah setiap proses kerja karena dalam SOP sudah diterangkan dengan rinci alur tugas masing-masing sehingga meminimalisir adanya kesalahan didalam proses pengerjaannya.

\section{Sistem Informasi Akuntansi}

Menurut Gelinas dan Dull (2010) sistem informasi akuntansi adalah subsistem khusus dari sistem informasi yang berfungsi untuk mengumpulkan, memproses, dan melaporan informasi yang berkaitan dengan aspek keuangan dari suatu kejadian bisnis. Menurut Hall (2011) sistem informasi akuntansi adalah suatu subsistem yang memproses transaksi keuangan dan nonkeuangan yang berpengaruh secara langsung terhadap pemrosesan transaksi keuangan. Bagranoff et al. (2010:5) menyatakan " $A n$ accounting information system is a collection of data and processing procedures that creates needed information for its users" yang berarti sistem informasi akuntansi adalah kumpulan dari data dan memproses prosedur-prosedur untuk menghasilkan informasi yang dibutuhkan bagi para penggunanya. Dengan demikian, dalam suatu organisasi terutama yang berorientasi profit dan bisnis, arus informasi merupakan hal yang krusial terkait pengambilan keputusan dan bagi pihak eksternal yang berkepentingan. Informasi adalah data yang telah dibuat ke dalam bentuk yang memiliki arti dan berguna bagi manusia.

Gantino dan Soeratno (2014) menyatakan bahwa sistem informasi adalah rangkaian prosedur formal dimana data dikumpulkan, diproses menjadi informasi dan didistribusikan kepada para pemakai. Nilai tambah dari sistem informasi adalah memperbaiki kualitas dan mengurangi biaya produksi dan jasa, memperbaiki efisiensi, memperbaiki decision making capabilities serta menaikkan the sharing of knowledge. Terdapat tiga aktivitas pada sistem informasi yaitu (1) Input adalah sekumpulan data mentah dalam organisasi maupun diluar organisasi untuk diproses dalam suatu sistem ekonomi; (2) Processing adalah konversi atau pemindahan, manipulasi dan analisis input mentah menjadi bentuk yang lebih berarti bagi manusia; (3) Output adalah distribusi informasi yang sudah diproses ke anggota organisasi dimana output tersebut akan digunakan. Sistem akuntansi menurut Rizqisenoaji (2014) merupakan dokumen yang terdiri atas bukti transaksi, alat-alat pencatatan, laporan dan prosedur yang digunakan perusahaan untuk mencatat transaksi dan kemudian melaporkan hasilnya. Konsisten dengan penelitian dari Agung (2015) yang menyatakan bahwa sistem informasi akuntansi merupakan kumpulan subsistem yang saling berhubungan satu sama lain dan bekerja sama secara harmonis untuk mengolah data 


\section{Jurnal Ekonomi Modernisasi, 13 (2) 2017, 78-93}

keuangan menjadi informasi keuangan yang dipersyaratkan oleh pihak manajemen dalam proses pengambilan keputusan di bidang keuangan.

Sistem informasi akuntansi dapat digunakan untuk memberikan informasi keuangan yang dibutuhkan oleh manajemen suatu perusahaan guna memudahkan pengelolaan keuangan perusahaan. Adanya sistem akuntansi yang baik diharapkan pengelolaan berbagai hal yang berkaitan dengan keuangan perusahaan. Oleh karena itu, sistem informasi akuntansi lebih luas dapat diartikan sebagai siklus pemprosesan transaksi atau penggunaan teknologi informasi dan pengembangan sistem informasi.

\section{Manajemen Taman Pendidikan Alquran}

Manajemen pendidikan Islam menurut Upe (2012) adalah manajemen yang diselenggarakan atau didirikan dengan hasrat dan niat untuk menerapkan ajaran dan nilai-nilai Islam dalam bentuk manajemen baik pendidikan formal maupun informal, seperti PAUD, dan TPQ

Fungsi manajemen menurut Maidawati (2010) yaitu, Planning yang meliputi 1) menetapkan, mendeskripsikan, dan menjelaskan tujuan, 2) memprakirakan, 3) menetapkan syarat dan dugaan tentang kinerja, 4) menetapkan dan menjelaskan tugas untuk mencapai tujuan, 5 ) menetapkan rencana penyelesaian, 6) menetapkan kebijakan, 7) merencankan sandar-standar dan metode penyelesaian, 8) mengetahui lebih dahulu permasalahana yang mungkin dihadapi. Organizing yang meliputi, 1) mendeskripsikan (pekerjaan dalam pelaksanaan, 2) mengklasifikasikan tugas pelaksanaan dalam pekerjaan operasional, 3) mengumpulkan pekerjaan operasional dalam satuan yang terkait dan dapat dikelola, 4) menetapkan syarat pekerjaan, 5) mengkaji dan menempatkan individ pada pekerjaan yang tepat, 5) mendelegasikan otoritas yang tepat kepada masing-masing bagian 6) memberikan fasilitas ketenagakerjaan dan sumber daya, 7) menyesuaikan organisasi ditinjau dari sudut hasil pengenalian. Actuating yang meliputi, 1) menjelaskan tujuan kepada bawahan, 2) mengelola dan mengajak bawahan bekerja maksiamal, 3) membimbing bawahan untuk mencapai standart operasional, 4) mengembangkan bawahan guna merealisasikan secara penuh, 5) memberikan orang hak untuk mendengarkan, 6) memuji dan member sanksi secara adil, 7) memberikan hadiah melalui penghargaan dan pembayaran untuk pekerjaan yang diselesaikan dengan baik. Controlling meliputi, 1) membandingkan hasil dan rencana pada umumnya, 2) menilai hasil dengan standart hasil pelaksanaan, 3) menciptakan alat yang efektif untuk mengukur pelaksanaan, 4) memberitahukan alat pengukur, 5) memudahkan data yang detail dalam bentuk perbandingan dan pertentangan, 6) menganjurkan tindakan perbaikan, 7) memberitahukan anggota tentang interpretasi yang bertanggung jawab, 8) menyesuaikan pengalian dengan hasil.

\section{Metode}

\section{Model Penelitian Pengembangan}

Penelitian pengembangan merupakan bagian dari penelitian desain yang digunakan sebagai salah satu metode ilmiah untuk mencari solusi memperbaiki 


\section{Devia Nurbatin / Model Pengembangan Sistem Informasi Akuntansi....}

praktik dari fenomena-fenomena dalam praktik pembelajaran melalui perpaduan penelitian dasar (basic research) dengan penelitian terapan (applied research). Lebih lanjut Nurbatin (2016) menyatakan bahwa untuk penelitian analisis kebutuhan sehingga mampu dihasilkan produk yang bersifat hipotetik sering digunakan metode penelitian dasar (basic research). Selanjutnya untuk menguji produk yang masih bersifat hipotetik tersebut, digunakan eksperimen atau action research. Setelah produk teruji, maka dapat diaplikasikan.
Berdasarkan hal tersebut, peneliti menggunakan model penelitian pengembangan karena peneliti membuat kerangka berfikir yang didasarkan pada analisis kebutuhan yang kemudian dituangkan dalam bentuk Standard Operating Procedure (SOP). Langkah-langkah pengembangan yang dilakukan oleh peneliti mengikuti pendekatan model Fitriana (2016). Namun demikian peneliti melakukan modifikasi yang disesuaikan dengan tujuan dan kebutuhan penelitian yang disajikan pada Gambar 1. berikut ini

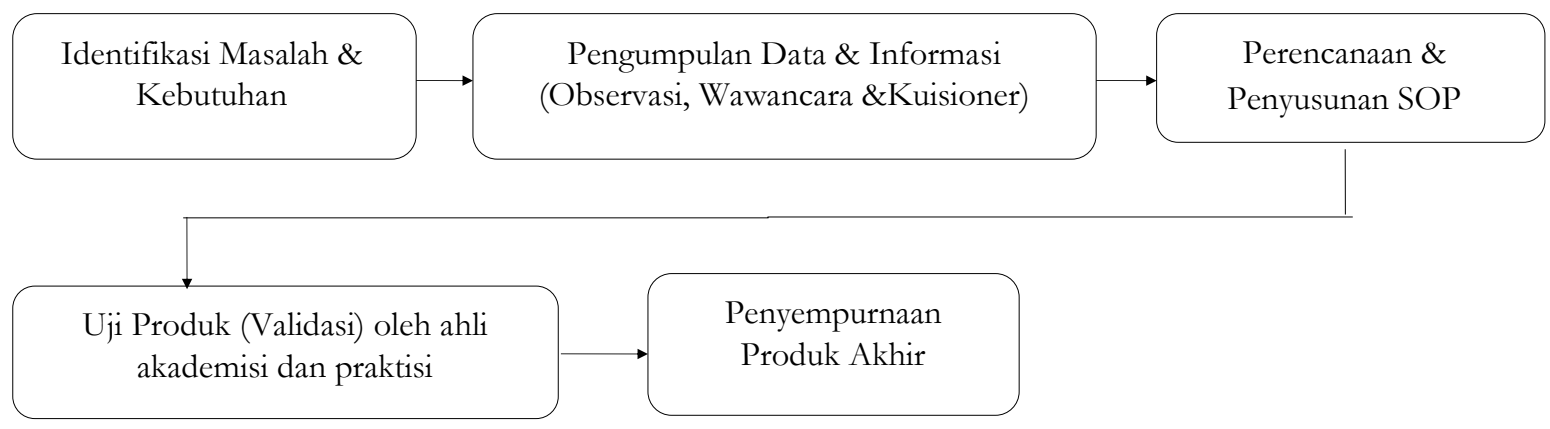

Gambar 1. Prosedur Pengembangan Penelitian Modifikasi Peneliti

Alasan pemilihan model Fitriana (2016) sebagai acuan untuk membuat modifikasi prosedur penelitian pengembangan, yaitu (1) langkah-langkah penelitian pengembangannya sederhana serta mudah untuk diaplikasikan; (2) Proses pengumpulan data yang dilakukan dapat membantu peneliti untuk membuat SOP sesuai kebutuhan bidang pendidikan khususnya pendidikan non-formal; (3) urutan tiap tahapan tersusun secara sistematis sehingga pelaksanaan lebih terkontrol dengan baik; (4) penghematan waktu, biaya dan tenaga sehingga menguntungkan bagi peneliti dalam melakukan uji coba produk atau tahap validasi produk; (5) uji coba pemakaian dan revisi produk berikutnya tidak digunakan, karena setelah dilakukan revisi produk dari pihak ahli akademisi dan praktisi langsung dilakukan penyempurnaan produk akhir atau dicetak berupa buku sistem mutu Alur Informasi Pencatatan Keuangan dan Alur Informasi Pengelolaan dan Pengendalian Keuangan.

\section{Prosedur Penelitian Pengembangan pada TPQ}

Penelitian pengembangan dilakukan dalam lima tahapan prosedur, yaitu: Pertama, Identifikasi Masalah dan Kebutuhan. Identifikasi kebutuhan merupakan tahap awal pengembangan sistem mutu 
akuntansi dan pengelolaan keuangan TPQ Al-Hidayah Dau Malang melalui observasi dan wawancara. Hasil observasi dan wawancara dengan pihak lembaga TPQ, diperoleh informasi bahwa lembaga pendidikan TPQ belum memiliki sistem mutu khususnya sistem akuntansi sebagai informasi pencatatan dan pengelolaan keuangan yang merupakan informasi penting bagi pihak manajemen pengelola TPQ. Sistem yang ada masih tidak baku dan bahkan tidak tertulis untuk ukuran pendidikan non formal sehingga pihak manajemen pengelola TPQ mengalami kesulitan dalam mengontrol serta meningkatkan kinerja. Oleh karena itu perlu dilakukan revisi produk terhadap sistem mutu yang masih tidak tertulis yang telah ada sebelumnya di TPQ Al-Hidayah. Revisi dilakukan berdasarkan masukan dari para validator ahli Kedua, tahap pengumpulan data. Pada tahap ini, peneliti mengumpulkan data-data atau informasi yang dapat dijadikan bahan untuk pengembangan produk sistem mutu yang berwujud SOP. Tujuannya agar peneliti dapat menentukan beberapa aspek dalam SOP yang dirangkai dan dikembangkan agar dapat mengatasi permasalahan dalam prosedur kerja juga membantu peningkatan kinerja pelaksanaan TPQ. Data dikumpulkan dengan cara : 1). Wawancara untuk mendapatkan gambaran umum permasalahan yang ada dalam aktivitas pelaksanaan manajemen TPQ mulai dari pendaftaran siswa-siswi, dana donasi dari para donatur dan bagaimana pencatatan serta pengelolaan keuangan di lembaga TPQ tersebut. 2). Pengamatan yang dilakukan dengan melihat aktivitas di lapangan terkait efektivitas operasional TPQ
3). Dokumentasi untuk mengumpulkan data yang diambil dari dokumen fisik terkait aktivitas administrasi dan proses belajar mengajar di TPQ; 4). Kuesioner (Angket) yang dilakukan untuk menguji tingkat validitas (uji coba) dari sistem mutu yang berwujud SOP.

Adapun tahap ketiga adalah perencanaan dan penyusunan SOP yang bertujuan untuk menyusun hasil penelitian dalam bentuk SOP yang akan diciptakan serta dikembangkan. Kegiatan ini bertujuan mengidentifikasi adanya kekurangan SOP sistem mutu yang telah ada. Tahap keempat adalah Uji Produk (Validasi) Oleh Ahli Akademisi dan Praktisi. Kegiatan ini bertujuan untuk mengetahui apakah SOP yang telah dibuat layak pakai. Validator terdiri dari dua ahli dosen akuntansi dan dan satu ahli praktisi lapangan dari pihak pengelola manajemen TPQ Al-Hidayah Kec. Dau, Malang. Dosen validator merupakan dosen jurusan Akuntansi yang memiliki keahlian praktisi dan pengalaman dalam penulisan SOP khususnya bidang konsentrasi akuntansi, pengembangan sistem mutu keuangan dan pajak. Ahli praktisi yang menjadi validator adalah Staf administrasi keuangan yang mengelola pembukuan administrasi kesiswaan pada TPQ Al-Hidayah DAU Malang sekaligus merupakan pengajar di beberapa pendidikan non formal tidak hanya di TPQ Al-Hidayah DAU Malang namun juga di PAUD yang berbasis pendidikan agama Islam. Tentunya ahli praktisi ini selain memiliki kemampuan pembukuan keuangan yang mengetahui kondisi di TPQ Al-Hidayah DAU Malang juga memiliki pengalaman bagaimana standar mutu selayaknya diterapkan dibeberapa pendidikan non-formal TPQ se- 


\section{Devia Nurbatin / Model Pengembangan Sistem Informasi Akuntansi....}

jenis. Berikut adalah identitas dari validator untuk penelitian ini : Gusnar Mustapa,SE.,MM (Dosen STIE IndocaktiMalang), Ary Yunita Anggraeni, SE.,MSA (Dosen Universitas Kanjuruhan), Dzakirotul M. (Administrasi Keuangan TPQ Al-Hidayah DAU Malang). Adapun tahap terakhir adalah Penyempurnaan Produk Akhir merupakan hasil yang diperoleh dari uji lapangan skala kecil yang digunakan sebagai acuan untuk melakukan revisi terhadap SOP yang dihasilkan sebelumnya. Penyusunan produk akhir pengembangan berupa susunan SOP Alur Informasi Pencatatan Keuangan dan SOP Alur Informasi Pengelolaan dan Pengendalian Keuangan. Produk ini adalah akhir dari revisi yang sesuai dengan saran dari validator, sehingga produk telah memiliki relevansi dan kesesuaian antara isi SOP yang diciptakan dengan SOP yang dikembangkan sehingga dapat bermanfaat bagi kebutuhan pelaksanaan manajemen dan operasional TPQ Al-Hidayah DAU Malang.

\section{Validasi (Uji Coba) Produk}

Validasi produk merupakan kegiatan untuk menilai dan menguji apakah rancangan produk, dalam hal ini sistem kerja baru secara rasional akan lebih efektif dari yang lama atau tidak (Sugiono, 2010). Uji coba produk ini dilakukan untuk mengetahui apakah produk yang telah dibuat/dirancang dalam penelitian ini yaitu produk standar operasional prosedur (SOP) layak digunakan atau tidak. Uji coba produk juga dilakukan untuk mengetahui sejauh mana produk ini dapat mencapai tujuan bagi objek yang diteliti. Validasi atau Uji coba produk dalam penelitian ini meli- puti tahap-tahap sebagai berikut : 1). Desain Validasi. Desain validasi dilakukan untuk mengetahui tingkat kegunaan, kemudahan pengguanaan, dan kelengkapan produk yang sedang dikembangkan sebelum produk digunakan. Hasil akhir dari kegiatan ini berupa desain produk lengkap dengan spesifikasi siap untuk diuji coba. Desain produk yang disusun berupa sistem mutu dalam bentuk Standard Operating Procedure. 2). Menentukan subjek validasi. Subjek uji coba yang terkait dengan pengembangan produk sistem mutu Informasi Pencatatan Keuangan dan Informasi Pengelolaan dan Pengendalian Keuangan terdiri dari Pihak Akademisi dan Praktisi 3). Menentukan jenis data yang diperolehyang terdiri dari jenis data primer dan sekunder. Data Primer adalah data wawancara kepada Pembina TPQ, Kepala Sekolah serta seluruh staf/karyawan di TPQ Al-Hidayah DAU Malang. Sedangkan Data Sekunder diambil dari survey yang dilakukan untuk melengkapi data primer berupa kajian literatur yang berkaitan. Pengumpulan data sekunder juga diambil berupa data-data yang tersedia yang diberikan langsung oleh pihak pengelola TPQ Al -Hidayah Dau Malang. 4). Pengumpulan data yang dilakukan berdasarkan setting dan sumber data. Pada penelitian ini teknik pengumpulan data menggunakan observasi, wawancara terhadap pembina TPQ, Kepala Sekolah serta staf keuangan dan beberapa Guru di TPQ Al-Hidayah DAU Malang. Untuk melakukan wawancara, peneliti menggunakan langkah-langkah antara lain: menentukan topik, menentukan narasumber lain dan menyusun kerangka wawancara (topik dan susunan pertanyaan). Adapun kuesioner digunakan untuk 


\section{Jurnal Ekonomi Modernisasi, 13 (2) 2017, 78-93}

mendapatkan validasi. Lembar validasi dianalisis untuk menentukan kelayakan sistem sekaligus sebagai panduan dalam revisi produk. Lembar validasi digunakan untuk mengumpulkan data sebagai aspek penilaian terkait manfaat SOP, kemudahan penggunaan SOP, kelengkapan SOP dan keterbacaan SOP. Adapun lembar validasi ahli terdiri dari 3 lembar validasi penilaian atau tanggapan masing-masing untuk pihak akademisi dan pihak praktisi. Instrumen validasi ahli yang digunakan adalah perpaduan angket tertutup dan terbuka. Bentuk angket penilaian menggunakan format rating scale terhadap produk yang dikembangkan. Isi angket tersebut berupa pernyataan judul-judul SOP yang terkait Alur Informasi Pencatatan Keuangan dan Alur Informasi Pengelolaan dan Pengendalian Keuangan. Rating scale menggunakan skala likert dengan 4 kategori skor. Tiap skor memiliki bobot yaitu skor $1=$ sangat rendah; skor $2=$ rendah; skor $3=$ Tinggi; skor 4=sangat tinggi. Angket tertutup digunakan untuk memudahkan pengisian jawaban yang praktis dan cepat bagi responden dan memudahkan bagi peneliti untuk menganalisis data kuantitaif. Angket terbuka digunakan untuk memberikan data kualitatif berupa revisi saran dan komentar dari responden terkait sistem mutu akuntansi dan pengelolaan keuangan. 5). Teknik analisis data pada tahap validasi menggunakan mean atau rata-rata hitung sampel yaitu :

$$
\bar{X}=\frac{\sum X}{n}
$$

Keterangan :

$\mathrm{X}=$ nilai rata - rata

$\sum \mathrm{X}=$ jumlah skor jawaban penelitian

$\mathrm{n}=$ jumlah total data atau pengamatan
Jawaban angket menggunakan skala Likert dengan kategori pilihan yang dimodifikasi dari Sugiono (2014) yaitu jika angka terkiri dari yang harus dihilangkan hanya angka 5 atau 5 yang diikuti oleh angka - angka nol belaka, maka angka paling kanan dari yang mendahuluinya tetap jika ia genap, bertambah satu jika ia ganjil. Berdasarkan hasil perhitungan skala likert tersebut, peneliti mengkategorikan menjadi 5 pembulatan yaitu:

1) Angka 4 berarti Sangat tinggi atau kriteria sangat layak

2) Angka 3 berarti Tinggi atau kriteria layak

3) Angka 2 berarti Cukup rendah atau kriteria tidak layak

4) Angka 1 berarti rendah atau kriteria sangat tidak layak

\section{Hasil dan Pembahasan}

\section{Paparan Data dan Obyek Penelitian}

Obyek penelitian ini adalah lembaga pendidikan non-formal Islam dalam bentuk TPQ bernama Al-Hidayah yang berdiri tahun 2004 dan berlokasi di Perumahan Taman Embong Anyar II Dusun Jetis, Desa Mulyoagung, Kecamatan Dau, Kabupaten Malang. TPQ Al-hidayah merupakan lembaga pendidikan agama Islam untuk anak-anak usia dini. TPQ didirikan di lingkungan perrumahan karena pendidikan agama untuk anak usia dini masih belum ada di Taman Embong Anyar II Mulyoagung, Dau, Malang, sehingga perlu didirikan TPQ untuk meningkatkan pemahaman agama anak usia dini terutama di lingkungan perumahan dan sekitarmya.

Berikut deskripsi pekerjaan masingmasing bagian. 


\section{Devia Nurbatin / Model Pengembangan Sistem Informasi Akuntansi....}

Tabel 1. Dekripsi Pekerjaan per Unit Kerja

\begin{tabular}{|c|c|}
\hline Unit Kerja & Deskripsi Pekerjaan \\
\hline Pembina TPQ & $\begin{array}{l}\text { Sebagai owner pendiri TPQ yang mendirikan lembaga pendidikan non- } \\
\text { formal basis agama Islam sekaligus aktif mengawasi, berkontribusi } \\
\text { terhadap tumbuh kembangnya lembaga TPQ Al-Hidayah DAU Malang } \\
\text { serta }\end{array}$ \\
\hline Kepala Sekolah TPQ & $\begin{array}{l}\text { Perencana, penyusun dan pelaksana program kerja pendidikan TPQ, } \\
\text { melaksanakan monitoring dan evaluasi kerja terhadap seluruh aspek } \\
\text { bidang di lembaga TPQ Al-Hidayah DAU Malang }\end{array}$ \\
\hline $\begin{array}{l}\text { Administrasi Keuangan } \\
\text { (Bendahara yayasan) }\end{array}$ & $\begin{array}{l}\text { Sebagai pengelola pembukuan dan pencatatan dana masuk dan dana } \\
\text { keluar dari seluruh aktivitas unit kerja di lembaga TPQ DAU Malang } \\
\text { serta bertanggung jawab kepada Pembina dan Kepala Sekolah untuk } \\
\text { laporan keuangan harian dan bulanan yang telah dibuat }\end{array}$ \\
\hline Bidang Kesiswaan & $\begin{array}{l}\text { Sebagai pengelola dan pengawas di bidang akademik melalui laporan } \\
\text { progres siswa-siswi dan Guru serta bertanggung jawab atas laporan } \\
\text { progres kegiatan belajar mengajar TPQ Al-Hidayah kepada Kepala } \\
\text { Sekolah }\end{array}$ \\
\hline Guru & $\begin{array}{l}\text { Sebagai pengajar/pendidik dan membimbing siswa siswi serta } \\
\text { bertanggung jawab atas laporan evaluasi proses belajar mengajar siswa } \\
\text { siswi kepada Kepala Sekolah dan Bidang Kesiswaan }\end{array}$ \\
\hline
\end{tabular}

Sumber : TPQ Al-Hidayah 2017

Hasil penelitian melalui observasi ditermukan beberapa hal, yaitu: 1). Belum ada pembukuan keuangan yang baik karena alur pencatatan aktivitas dana masuk dan keluar masih manual dan seadanya sehingga tidak ada laporan keuangan untuk informasi pembina, 2). Belum laporan keuangan yang dapat memberikan informasi akurat kepada pihak pengelola menajemen, sehingga pihak manajemen tidak dapat melakukan perencanaan, pengawasan, pengendalian dan evaluasi terhadap anggaran lembaga TPQ Al-Hidayah DAU Malang, sebagai dasar evaluasi yang digunakan untuk menyusun program pada tahun berikutnya. Hal ini menghambat kinerja manajemen TPQ Al-Hidayah, Mulyoagung, Dau, Malang.

Berdasarkan standar mutu yang telah direncanakan dan penyusunannya terdiri dari elemen-elemen yaitu (1) Judul SOP; (2) Tanda Pengesahan dari lembaga Taman Pendidikan Alquran Al-Hidayah DAU Malang; (3) Definisi Standar Prosedur; (4) Tujuan Standar Prosedur; (5) Tahap-tahap Prosedur Kerja; (6) Bagian Terkait pelaksanaan Standar Prosedur (petugas); (7) Perangkat Standar Prosedur Setelah melakukan perencanan SOP, kemudian dilakukan penyusunan SOP dalam bentuk naskah yang kemudian diuji dan divalidasi oleh tiga validator ahli bidang Akuntansi dan Keuangan, serta dikonfirmasi langsung kepada pembina dan kepala sekolah TPQ Al-Hidayah DAU Malang. Validator ahli akan menilai SOP dari aspek tingkat kegunaan, kemudahan, kelengkapan, dan keterbacaan. Berikut ini merupakan data pengelompokan hasil konversi perhitungan nilai rata-rata SOP yang telah divalidasi. 


\section{Jurnal Ekonomi Modernisasi, 13 (2) 2017, 78-93}

Tabel 2. Hasil Validasi Standar Operasional Prosedur

\begin{tabular}{|c|c|c|c|c|}
\hline Aspek & $\begin{array}{l}\text { Akade- } \\
\text { misi } 1\end{array}$ & $\begin{array}{l}\text { Akade- } \\
\text { misi } 2\end{array}$ & Praktisi & Rata2 \\
\hline SOP pencatatan tagihan rekening pelunasan beban utili- & 3 & 3,75 & 3,25 & 3,33 \\
\hline SOP Pencatatan administrasi iuran SPP siswa-siswi & 3,25 & 3,75 & 4 & 3,67 \\
\hline SOP Pencatatan pembayaran beban Honorarium dan & 3,75 & 3,75 & 3,5 & 3,67 \\
\hline $\begin{array}{l}\text { SOP Pencatatan Pengadaan Barang elektronik sebagai } \\
\text { fasilitas/media belajar mengajar dan alat tulis kantor/ } \\
\text { akademik }\end{array}$ & 3,25 & 3,75 & 3,5 & 3,5 \\
\hline SOP Pencatatan Pengadaan stock Kartu Prestasi Belajar & 3 & 3,25 & 3,25 & 3,17 \\
\hline SOP Pencatatan pembayaran beban tunjangan (bonus, & 3,75 & 4 & 4 & 3,92 \\
\hline SOP Pencatatan dana masuk internal dan eksternal TPQ & 3,5 & 3,75 & 3,5 & 3,58 \\
\hline SOP Pencatatan dana keluar internal dan ekternal TPQ & 3,25 & 3,75 & 3,75 & 3,58 \\
\hline $\begin{array}{l}\text { SOP Alur Penyusunan Buku Besar TPQ Al-Hidayah } \\
\text { DAU Malang }\end{array}$ & 3 & 4 & 3,5 & 3,5 \\
\hline SOP Alur penyusunan Laporan Laba Rugi TPQ Al- & 3 & 3,25 & 4 & 3,42 \\
\hline $\begin{array}{l}\text { SOP Perencanaan dan Realisasi Anggaran Pengadaan } \\
\text { Barang elektronik fasilitas/media belajar mengajar dan } \\
\text { alat tulis kantor/akademik }\end{array}$ & 3 & 3,75 & 4 & 3,59 \\
\hline $\begin{array}{l}\text { SOP Perencanaan, pengendalian dan pengawasan Real- } \\
\text { isasi Anggaran Pengelolaan keuangan di unit kerja TPQ }\end{array}$ & 3,25 & 3,5 & 4 & 3,59 \\
\hline $\begin{array}{l}\text { SOP Perencanaan, pengendalian dan pengawasan real- } \\
\text { isasi anggaran beban pelatihan kompetensi Guru dan } \\
\text { staff unit kerja }\end{array}$ & 3,75 & 3,75 & 3,75 & 3,75 \\
\hline $\begin{array}{l}\text { SOP Pengendalian dan Pengawasan Anggaran Kegiatan } \\
\text { penunjang TPQ (Pawai TPQ) }\end{array}$ & 3,75 & 3,75 & 4 & 3,83 \\
\hline $\begin{array}{l}\text { SOP Pengendalian dan Pengawasan Anggaran Kegiatan } \\
\text { penunjang TPQ (Pondok Ramadhan) }\end{array}$ & 3 & 3,25 & 3,75 & 3,33 \\
\hline $\begin{array}{l}\text { SOP Pengendalian dan Pengawasan Anggaran Kegiatan } \\
\text { penunjang TPQ Rekreasi siswa-siswi beserta staf/unit } \\
\text { kerja di TPQ }\end{array}$ & 3 & 3,5 & 3,75 & 3,42 \\
\hline SOP pengendalian dan pengawasan Anggaran Pem- & 3,25 & 3,75 & 4 & 3,67 \\
\hline SOP pemgemdalian dan pengawasan Anggaran kegiatan & 3,75 & 4 & 4 & 3,92 \\
\hline Total & 59,5 & 66,3 & 67,5 & 64,4 \\
\hline Rata-Rata & 3,3 & 3,7 & 3,8 & 3,6 \\
\hline
\end{tabular}

Sumber : Data diolah 2017 


\section{Devia Nurbatin / Model Pengembangan Sistem Informasi Akuntansi....}

Berdasarkan hasil perhitungan total rata-rata keseluruhan, diperoleh skor 3,6 yang dibulatkan menjadi 4 . Skor tersebut termasuk dalam kategori sangat tinggi sehingga SOP yang dibuat peneliti untuk sistem mutu akuntansi dan pengelolaan keuangan dikategorikan sangat layak untuk digunakan dan diterapkan pada lembaga Taman Pendidikan Alquran Al-Hidayah DAU Malang.

Hasil yang diperoleh kegiatan penilaian validasi SOP dan uji lapangan skala kecil digunakan sebagai acuan untuk melakukan revisi terhadap SOP yang dihasilkan sebelumnya. Revisi dilakukan berdasarkan penilaian dan masukan berupa revisi dari beberapa aspek dalam SOP dari para ahli validator serta analisis perhitungan uji rata-rata perhitungan statistik.

Langkah selanjutnya adalah penyempurnaan produk akhir yang berupa susunan naskah tertulis Standar Operasional Prosedur dan Standar Operasional Prosedur Alur Informasi Pencatatan Keuangan dan Alur Informasi Pengelolaan dan Pengendalian Keuangan yang telah direvisi sesuai saran validator melalui pengujian lapangan, sehingga produk SOP ini telah memiliki relevansi dan kesesuaian antara isi SOP yang telah diciptakan dengan SOP yang dikembangkan lebih lanjut sehingga bermanfaat bagi pelaksanaan manajemen TPQ.

\section{Tahap Revisi Produk}

Secara garis besar produk SOP yang dihasilkan, dapat diterima secara substantif oleh validator. Masukan yang diberikan oleh validator hanya bersifat saran dan tidak merubah alur pikir SOP yang disusun. Adapun saran yang diberikan oleh para validator adalah

SOP Alur Informasi Pencatatan Keuangan dan SOP Alur Informasi Pengelolaan dan Pengendalian Keuangan sudah wajar sesuai prosedur mutu dalam bidang akuntansi dan keuangan. Namun perlu pembenahan redaksional kalimat agar mudah dipahami per langkah di setiap prosedur SOP, seperti mempertegas kalimat "langkah" disetiap prosedur serta menyebutkan pihak-pihak terkait yang bertanggung jawab dan mengotorisasi informasi keuangan dalam laporan keuangan;

SOP Alur Informasi Pencatatan Keuangan dan SOP Alur Informasi Pengelolaan keuangan dari segi kegunaan, kemudahan, kelengkapan sudah menggambarkan kebutuhan dan kondisi yang sebenarnya di lapangan sehingga memungkinkan mudah dipahami dan dijalankan oleh seluruh aspek yang terlibat dalam pelaksanaan manajemen TPQ AlHidayah DAU Malang.

\section{Produk Akhir}

Berdasarkan revisi produk standar mutu hingga penyempurnaan maka terbentuklah Standar Operational Prosedur (SOP) Alur Informasi Pencatatan Keuangan dan SOP Alur Informasi Pengelolaan keuangan. SOP Alur Informasi Pencatatan Keuangan yang berkonsep dan beracuan pada substansi Akuntansi yang dihasilkan dapat berperan sebagai informasi, pedoman, acuan dan petunjuk kerja pihak pembina atau pengelola manajemen TPQ Al-Hidayah dalam hal perencanaan, pengelolaan hingga 
pencatatan pelaporan keuangan. SOP Alur Informasi Pengelolaan keuangan.yang beracuan pada substansi manajemen keuangan diharapkan dapat memberikan pedoman dan petunjuk meningkatkan kinerja dan keberlangsungan lembaga TPQ melalui peningkatan kualitas pelayanan pendidikan agar mampu bersaing dengan lembaga TPQ sejenis dilingkungan sekitar.

\section{Simpulan}

Berdasarkan Standar Operasional Prosedur (SOP) yang telah disusun diperoleh kesimpulan yaitu 10 SOP Alur Informasi Pencatatan Keuangan dan 8 SOP Alur Informasi Pengelolaan dan Pengendalian Keuangan yang memperoleh skor tinggi. Secara keseluruhan dapat diisimpulkan bahwa SOP Alur Informasi Pencatatan Keuangan dan SOP Alur Informasi Pengelolaan dan Pengendalian Keuangan (Tabel 4) yang disusun oleh peneliti layak untuk digunakan lembaga TPQ berbasis agama Islam karena sesuai dengan kebutuhan lembaga itu sendiri, dan mudah dipahami dan diterapkan.

Adapun saran yang diberikan oleh validator adalah peneliti diharapkan dapat mengembangan sistem mutu yang lebih inovatif bagi lembaga pendidikan sejenis TPQ agar target pendidikan berbasis agama yang menghasilkan anak didik yang berkualitas serta memiliki target waktu pelaksanaan SOP. Harapannya agar seluruh aspek yang terkait dapat merasakan manfaat dari SOP tersebut. Sedangkan saran dari kepala sekolah dan bagian administrasi keuangan (bendahara) peneliti dapat terlibat langsung dalam proses pelaksanaan SOP, melalui proses pengamatan dalam jangka waktu tertentu sehingga peneliti dapat mengetahui hasil manfaat SOP yang telah disusun, serta membuat evaluasi pelaksanaan SOP agar mampu mencapai sistem mutu yang berkualitas sesuai tujuan penelitian pengembangan.

Adapun keterbatasan penelitian ini adalah: 1). SOP yang disusun tidak didukung perencanaan target waktu yang tepat karena langsung diterapkan tanpa uji coba terlebih dahulu; 2). Peneliti tidak dapat melakukan pengambilan data dan informasi secara bertahap dan kontinyu sebagai progres pengamatan proses pelaksanaan SOP yang diterapkan. Hal ini dikarenakan keterbatasan informasi yang harus diperoleh dan keterbatasan periode perancangan penelitian lapangan yang ditargetkan oleh pihak akademisi.

Saran bagi peneliti selanjutnya adalah 1). Peneliti dapat menganalisis kebutuhan lembaga TPQ yang dikondisikan dengan lingkungan sekitar yang juga mendirikan lembaga TPQ sejenis, sehingga penelitian pengembangan sistem mutu dapat diterapkan dibidang sistem informasi akuntansi, sistem mutu operasional atau di sumber daya manusia. 2). Peneliti dapat melakukan uji validasi terhadap lebih dari 3 orang validator ahli, sehingga diperoleh analisis pengujian yang akurat dan masukan terhadap penyusunan SOP yang lebih baik lagi. Pengembangan terhadap pengujian produk yang tidak berhenti pada uji validator ahli. Pengujian yang dikembangkan seperti melakukan uji coba produk dan uji coba lapangan sehingga selain mampu mengidentifikasi apa yang menjadi kebutuhan perusahaan, SOP yang diuji coba akan lebih valid dan target sistem mutu berkualitas akan 


\section{Devia Nurbatin / Model Pengembangan Sistem Informasi Akuntansi....}

tercapai melalui proses pengamatan uji coba lapang.

\section{Daftar Pustaka}

Agung, Mulyo. (2015). Accounting Information System and Improvement On Financial Reporting. International Journal of Recent Advances in Multidisciplinary Research. 2(11), 950-957

Atmoko, Tjipto. (2012). Standar Operasional Prosedur (SOP) dan Akuntabilitas Kinerja Instansi Pemerintah. Skripsi. Universitas Padjajaran Bandung.

Bagranoff, Nancy A., Simkin, Mark G. dan Norman, Carolyn S. (2010). Core Concepts Of Accounting Information System. USA: John Wiley and Sons.

Chibueze Kalu, Ukah. (2011). Critical Success Factors For Accounting Information Systems Data Quality. Thesis, Department of Accountancy Faculty Of Business Administration University Of Nigeria.

Fitriana, Ghufriana. (2016). Penelitian dan Pengembangan Sistem Mutu Akuntansi Keuangan, Manajemen Keuangan, Pemasaran dan Operasional pada TPQ Al-Hidayah Malang. Skripsi. STIE Indocakti Malang.

Gantino, Soeratno, Rachman dan Anggraini. (2014). Perancangan dan Implementasi Sistem Informasi Manajemen pada TPQ Kecamatan PuloGadung. Jurnal Riset Akuntasi. 6(2), 77-110
Gelinas, U.J., dan Dull, R.B. (2010). Accounting Information Systems (8th edition). Ohio: South-Western Cengage Learning.

Mulyadi. (2016). Sistem Akuntansi. Cetakan ke-4 Edisi Ketiga. Penerbit Salemba Empat: Jakarta.

Maidawati. (2010). Pengantar Manajemen. Padang: Limlet IAIN.

Nurbatin, Defia. (2016). Sebuah Model Penelitian dan Pengembangan Sistem untuk Pengelolaan Keuangan dan Pelayanan Pada Bisnis Internet. Jurnal Riset dan Aplikasi Akuntansi dan Manajemen (JRAAM) Polinema. 1(3), 249-260

Prasanna. (2013). Standard Operating Procedures for Standalone Hotels. Research Journal of Management Science. Vol. 2(7), 1-9

Rizqisenoaji, Aditya. (2014). GAP Analisis Penerapan SAK ETAP Pada Penyusunan Laporan Keuangan UKM di Kabupaten Kudus. Skripsi. Fakultas Ekonomi dan Bisnis Universitas Diponegoro, Semarang.

Sugiono. (2010). Metode Penelitian Pendidikan. Bandung : Alfabeta.

Setiawati, W. (2015). Penyusunan Standard Operating Procedure (SOP) pada PT Sketsa Cipta Graha di Surabaya. Agora, 3(1), 514-522.

Santoso, Yudi dan Nurwanti. (2016). Rancangan Sistem Informasi Pendaftaran Siswa Baru. Seminar Nasional Inovasi dan Aplikasi Teknologi di Industri (SENIATI). Institut Teknologi Nasional Malang. 
Jurnal Ekonomi Modernisasi, 13 (2) 2017, 78-93

Sugiyono. (2014). Metode Penelitian Kuantitatif, Kualitatif, dan R\&D. Bandung: Alfabeta.

Susanto, Azhar. (2016). The Effect of Internal Control on Accounting Infromation System. International Bussiness Management 10(23), 55235529
Upe, Ambo. (2012). Manajemen Taman Pendidikan Alquran (TPQ) di Kecamatan Tembilahan Kabupaten Indragiri Hilir. Thesis. Program Pascasarjana Universitas Islam Negeri Sultan Syarif Kasim Riau. 